\title{
$\beta$-blockers in advanced cirrhosis: More friend than enemy
}

\author{
Ki Tae Yoon*, ${ }^{* \dagger}$ Hongqun Liu*, and Samuel S. Lee \\ Liver Unit, University of Calgary Cumming School of Medicine, Calgary, Canada
}

Nonselective beta-adrenergic blocker (NSBB) therapy for the prevention of initial and recurrent gastrointestinal bleeding in cirrhotic patients with gastroesophageal varices has been used for the past four decades. NSBB therapy is considered the cornerstone of treatment for varices, and has become the standard of care. However, a 2010 study from the group that pioneered $\beta$-blocker therapy suggested a detrimental effect of NSBBs in decompensated cirrhosis, especially in patients with refractory ascites. Since then, numerous additional studies have incompletely resolved whether NSBBs are deleterious, although more recent evidence weighs against a harmful effect. The possibility of a "therapeutic window" has also been raised. We aimed to review the literature to analyze the pros and cons of using NSBBs in patients with cirrhosis, not only with respect to bleeding or mortality but also to other potential benefits and risks. $\beta$-blockers are highly effective in preventing first bleeding and recurrent bleeding. Furthermore, NSBBs improve congestion/ischemia of the gut mucosa, decrease intestinal permeability, and therefore indirectly alleviate systemic inflammation. $\beta$-blockers shorten the electrocardiographic prolonged QTc interval and may also decrease the incidence of hepatocellular carcinoma. On the other hand, the possibility of deleterious effects in cirrhosis has not been completely eliminated. NSBBs may be associated with an increased risk of portal vein thrombosis, although this could be correlational artifact. Overall, we conclude that $\beta$-blockers in cirrhosis are much more of a friend than enemy. (Clin Mol Hepatol 2021;27:425436)

Keywords: Cirrhosis; Portal hypertension; Varices; Refractory ascites

"Keep your friends close, but your enemies closer."

- Dialogue spoken by Michael Corleone in "The Godfather Part

II," Paramount Pictures 1974

\section{INTRODUCTION}

Nonselective beta-adrenergic blockers (NSBBs) have been used in the management of portal hypertension in patients with cirrho-

\begin{abstract}
Abbreviations:
$\mathrm{ACLF}$, acute-on-chronic liver failure; $\mathrm{AKI}$, acute kidney injury; $\mathrm{Cl}$, confidence interval; CRP, C-reactive protein; ECG, electrocardiogram; HCC, hepatocellular carcinoma; HR, hazard ratio; HRS, hepatorenal syndrome; HVPG, hepatic venous pressure gradient; MAP, mean arterial pressure; NSBBs, nonselective betaadrenergic blockers; PICD, paracentesis-induced circulatory dysfunction; PVT, portal vein thrombosis; QTC, corrected QT interval; RCTs, randomized controlled trials; VBL, variceal band ligation
\end{abstract}

Corresponding author : Samuel S. Lee

Liver Unit, University of Calgary Cumming School of Medicine, 3330 Hospital Dr NW, Calgary, AB T2N 4N1, Canada

Tel: +1-403 220 8457, Fax: +1-403 5925090

E-mail: samlee@ucalgary.ca

https://orcid.org/0000-0003-4431-272X

*These authors contributed equally to the manuscript as first author. ${ }^{\dagger}$ Current address: Division of Gastroenterology and Hepatology, Department of Internal Medicine, Pusan National University College of Medicine and Liver center, Pusan National University Yangsan Hospital, Yangsan, Korea 
sis for the past 40 years. ${ }^{1,2}$ In 1980, Lebrec and colleagues ${ }^{1}$ conducted a randomized trial and found that propranolol, at doses reducing the heart rate by $25 \%$, significantly decreased the portal pressure in cirrhotic patients with portal hypertension. They speculated that the portal-hypotensive effect of propranolol might be useful in the prevention of recurrent bleeding caused by esophageal varices. This seminal study helped usher in the "golden age" of cardio-hepatology through research on cardiovascular anomalies in liver disease and vice-versa. Nowadays, NSBBs have been established as the standard of care to prevent variceal bleeding and rebleeding. ${ }^{3}$

What was not to like about $\beta$-blockers in cirrhosis? Numerous studies clearly demonstrated their efficacy in reducing the incidence of a first variceal bleed (primary prophylaxis) and rebleeding (secondary prophylaxis), with relatively few serious adverse effects (reviewed in Lebrec, ${ }^{4}$ Jakab and Garcia-Tsao, ${ }^{5}$ Korean Association for the Study of the Liver, ${ }^{6}$ and Brunner et al. ${ }^{7}$ ). The theoretical risk of reducing cardiac output and thereby inducing arterial hypotension and tissue ischemia proved to be generally unfounded, as the chronic $\beta$-blockade allowed unopposed $a$-adrenergic vasoconstriction to offset the reduction in cardiac output and maintain arterial pressure in most patients. ${ }^{4.8}$ Only a small percentage of cirrhotic patients showed significant hypotension after starting $\beta$-blockade. Furthermore, known adverse effects such as precipitation/worsening of asthma, increasing electrocardiographic first-degree heart block and reduced exercise tolerance were clinically insignificant in the vast majority of patients.

Therefore, in the world of liver research, it was surprising when Lebrec's group published a study suggesting that $\beta$-blocker therapy in patients with advanced cirrhosis and refractory ascites was associated with significant harms, such as decreased survival. ${ }^{9}$ As this came from the acknowledged "founding father" of $\beta$-blockers in portal hypertension, Lebrec's study received great attention, and several institutes attempted to confirm or refute this hypothesis.

$\beta$-blockers may exert harmful effects in cirrhotic patients by several potential mechanisms: 1) decreasing the mean arterial pressure (MAP), heart rate, and ventricular contractility, and thus diminishing organ perfusion; 2) precipitating acute kidney injury $\left.(A K I){ }_{i}^{10} 3\right)$ triggering paracentesis-induced circulatory dysfunction (PICD) after large-volume paracentesis; and 4) inducing a portalhypotensive effect that may increase the risk of occlusive portal vein thrombosis (PVT)." Besides the effects on variceal bleeding and the kidney, other potential benefits and harms have also been
Table 1. Summary of effects of $\beta$-adrenergic blockers

\begin{tabular}{ll}
\hline Beneficial effects & \multicolumn{1}{c}{ Deleterious effects } \\
\hline $\begin{array}{l}\text { Decrease variceal bleeding risk } \\
\text { a) Primary prophylaxis }\end{array}$ & Decrease survival in \\
b) Secondary prophylaxis & decompensated cirrhosis? \\
Decrease portal hypertensive & Decrease renal perfusion \\
gastropathy & \\
Decrease prolonged QTc interval & Increase portal vein thrombosis? \\
Decrease systemic inflammation? & \\
Decrease hepatocellular \\
carcinoma risk?
\end{tabular}

QTc, corrected QT interval; ?, controversial or unproven.

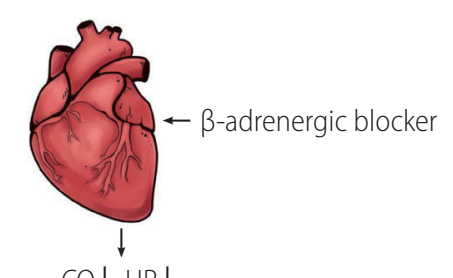

$\mathrm{CO} \downarrow \mathrm{HR} \downarrow$

Unopposed a-adrenergic vasoconstriction

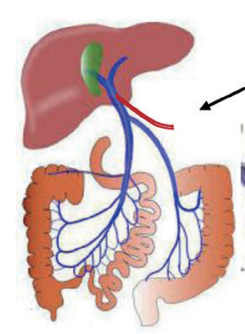

Gut blood flow $\downarrow$

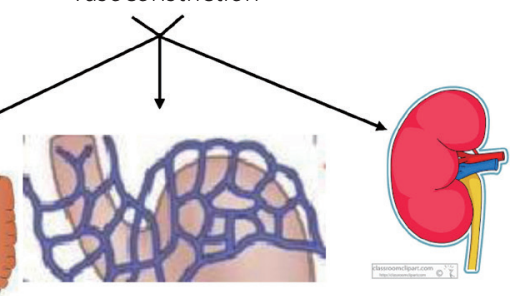

Variceal blood flow $\downarrow$ Variceal pressure $\downarrow$

Renal blood flow $\downarrow$ AKI?

PV blood flow $\downarrow$

PV pressure $\downarrow$

Hepatic artery flow $\downarrow$

Figure 1. Mechanisms underlying the effects of $\beta$-adrenergic blockade in cirrhotic patients. $\mathrm{CO}$, cardiac output; $\mathrm{HR}$, heart rate; $\mathrm{PV}$, portal vein; AKI, acute kidney injury.

suggested (Table 1). See Figure 1 for an overview of $\beta$-blockers' mechanisms of action. Here, we have reviewed the pros and cons of using non-selective $\beta$-blockers in patients with cirrhosis.

\section{NSBBS REDUCE PORTAL PRESSURE}

It is well-known that $\beta$-adrenoceptors increase cardiac conduction, heart rate, and contractility, and thereby increase cardiac output. Patients with cirrhosis are characterized by decreased ar- 
terial pressure and increased cardiac output, which is called hyperdynamic circulation. Among the multiple causes of hyperdynamic circulation, the adrenergic system plays a critical role, and the cardiovascular $\beta$-adrenoceptor is overdriven. The blockade of $\beta$-receptors should protect the heart from damage due to sympathetic overactivation which promotes catecholamine cardiotoxicity.

On the other hand, portal venous hypertension is derived from increased blood flow resistance in the liver and portal vein (backward flow theory), as well as increased mesenteric blood flow (forward flow theory). The hydrodynamic formula, $\mathrm{P}=\mathrm{Q} \times \mathrm{R}$ (portal pressure $=$ mesenteric blood flow $\times$ liver resistance), implies that the blockade of $\beta_{1}$-receptors decreases cardiac output, which reduces mesenteric blood flow and portal pressure. Another target of NSBBs is the $\beta_{2}$-adrenergic receptor, which vasodilates mesenteric circulation. The blockade of $\beta_{2}$-receptors allows an unopposed vasoconstrictive $a$-adrenergic effect in the splanchnic vasculature, $^{12}$ which also decreases blood flow and thus reduces pressure in the portal vein.

Poynard and colleagues ${ }^{13}$ analyzed four randomized controlled trials (RCTs) and found that in 2 years of follow-up, $78 \%$ of $\beta$-blocker treated-patients (two RCTs used propranolol, two nadolol) did not have upper gastrointestinal bleeding; this percentage was $65 \%$ in the controls $(P<0.01)$. About $90 \%$ of the patients on NSBB treatment had no fatal bleeding; this percentage was $82 \%$ in patients without NSBB treatment $(P=0.01)$. Moreover, $62 \%$ of the survivors in NSBB group did not experience variceal hemorrhage after 2 years; this percentage was $53 \%$ in patients without NSBB treatment $(P<0.05)$. After adjustment for the cause, severity of cirrhosis, ascites, and variceal size, NSBB groups still had fewer total bleeds $(P<0.01)$ and fatal bleeds $(P<0.01)$ compared to placebo controls. The authors concluded that $\beta$-blockers are effective for preventing first bleeding and reducing the mortality rate associated with gastrointestinal bleeding, regardless of the cirrhosis severity. ${ }^{13}$

Patients with acute-on-chronic liver failure (ACLF) who present with variceal bleeding represent a special subpopulation. In this particular group, a recent study reported by Shin and colleagues ${ }^{14}$ from the Korean ACLF consortium demonstrated that the presence of ACLF was associated with significantly increased mortality compared to those without ACLF.

Furthermore, Kumar and colleagues ${ }^{15}$ demonstrated that NSBB improves survival, and decreases the number of AKI and spontaneous bacterial peritonitis events in patients with ACLF. Therefore, NSBB may be a useful therapeutic agent for ACLF patients with variceal bleeding.
It is documented that a sizable minority, approximately $30-50 \%$ of patients with cirrhosis, do not respond to NSBB therapy hemodynamically with a significant drop in portal pressure. ${ }^{4,5,7}$ Interestingly, NSBBs have remained effective in the prevention of variceal hemorrhage in a large proportion of hemodynamic nonresponders. ${ }^{4,5,7}$ This suggests that NSBBs may prevent other triggers of variceal bleeding, such as inflammation and infection. ${ }^{16}$

\section{NSBBS ALLEVIATE SYSTEMIC INFLAMMATION}

Moreau and colleagues ${ }^{17}$ investigated the relationship between NSBBs and systemic inflammation in patients with ACLF, and found that the intensity of systemic inflammation (as judged by markers such as high leukocyte count and plasma C-reactive protein (CRP) concentration) parallels the severity of ACLF. The degree of inflammatory reaction was an independent predictor of post-enrolment development of ACLF and ACLF-associated mortality. Jalan et al. ${ }^{18}$ also found that, in patients with ACLF, the ability to resolve inflammation (reduce (RP) was correlated with the prognosis. Cazzaniga and coworkers ${ }^{19}$ studied not only patients with ACLF but also cirrhotic patients consecutively admitted to the hospital, and found that systemic inflammation is closely associated with the severity of liver disease, portal hypertension-related complications, and poor survival.

The mechanism underlying these changes may be the so-called "inflammatory phenotype" of cirrhosis. Patients with cirrhosis are prone to develop increased levels of bacteria and bacterial toxins in circulation. This is in part due to the defective innate immune function in cirrhosis, including defective bactericidal and opsonic activities, chemotaxis, phagocytosis, monocyte function, and low serum complement levels. ${ }^{20}$ In addition, the combination of portal hypertension congesting the gut mucosa and impaired bowel motility leads to increased intestinal permeability and bacterial overgrowth. ${ }^{21,22}$ As a result, these factors induce gut translocation of bacteria and endotoxin, and unleash a humoral and cell-mediated inflammatory response, known as the "inflammatory phenotype". ${ }^{21,23}$ In cirrhosis, the inflammatory phenotype may be involved in the pathogenesis of several cardiovascular complications, including cirrhotic cardiomyopathy. ${ }^{24}$

Several studies have found that NSBBs alleviate systemic inflammation. ${ }^{22,25,26} \beta$-blockers may exert this effect by reducing mesenteric venous congestion, as well as directly decreasing intestinal permeability. ${ }^{16,22,26}$ Mookerjee and coworkers ${ }^{26}$ demonstrated that NSBB treatment was associated with lower grades of ACLF, and 
significantly more patients with ongoing $\beta$-blocker treatment experienced improvement. This improvement was associated with a considerably lower white cell count. In comparison, patients who were not treated with $\beta$-blocker tended to show worsening of ACLF during their hospital stay. Furthermore, the patients who discontinued NSBB treatment had significantly higher 28-day and 3-month mortality rates. ${ }^{26}$

\section{NSBBS DECREASE ELECTROCARDIOGRAPHIC QT INTERVALS}

The QT interval on an electrocardiogram (ECG) is a measure of ventricular depolarization and repolarization. The QT interval must be corrected for the heart rate (QTC); and although there are several methods for doing this, the commonly-used Bazett formula should be avoided in favor of the more stringent Friedericia method. ${ }^{27}$ Approximately $30-60 \%$ of patients with cirrhosis have a prolonged QTc interval. ${ }^{28,29}$

Two previous studies reported that cirrhotic patients with prolonged QTc had significantly lower survival rates than those with normal QTc interval. ${ }^{30,31}$ However, these results must be confirmed by larger prospective observational studies, as this association may merely reflect that QT intervals generally correlate with the degree of liver dysfunction; in other words, more advanced cirrhosis shows greater prolongation of QTc. Peter and colleagues demonstrated that QTc, serum $\mathrm{Na}^{+}$concentration, and $\beta$-blocker use predicted the development of hepatorenal syndrome (HRS) in 78 consecutive patients who were admitted for variceal bleeding. ${ }^{32}$ However, as there were only 14 cases of HRS, this small study should be confirmed by larger trials.

$\beta$-blockers are known to decrease the QTc interval. ${ }^{33,34}$ Henriksen and colleagues ${ }^{33}$ found that acute $\beta$-blockade reduced cardiac output, heart rate, hepatic venous pressure gradient (HVPG), and QTC 90 minutes after an oral dose of propranolol. The decrease of QTC was observed only in cirrhotic patients with prolonged QTC, and not controls. Furthermore, the percentage decrease in QTC correlated with the reduction in HVPG and cardiac output. ${ }^{33}$ Zambruni et al. ${ }^{34}$ reported a similar result with nadolol dosed chronically over 1-3 months, with only the patients with prolonged QTC showing a decrease.

Although prolonged QTc has been associated with increased risk of ventricular arrhythmias and even sudden cardiac death in several noncirrhotic heart diseases, whether this still holds true in patients with cirrhosis is doubtful. To date, there is no convincing evidence that prolonged QT interval in cirrhosis is anything more than an electrophysiological curiosity, nor whether correcting the prolonged QT interval conveys any definite clinical benefit.

\section{NSBBS AND HEPATOCELLULAR CARCINOMA (HCC)}

There are several possible theoretical pathways by which NSBBs may reduce the incidence of HCC: 1) NSBBs decrease the portal pressure. Ripoll and colleagues demonstrated that HVPG is an independent predictor of HCC development. They divided patients into two groups based on a cut-off value of $10 \mathrm{mmHg}$ of HVPG, and found that patients whose HVPG were more than $10 \mathrm{mmHg}$ had a 6 -fold increase in the HCC incidence, ${ }_{1}^{35}$ 2) $\beta$-blockers inhibit the effect of catecholamines. It is well-known that catecholamines can stimulate cancer cell migration, invasiveness, and proliferation. Studies have demonstrated that NSBBs prevent or have therapeutic effects on different cancers such as gastric, pancreatic, and breast cancers; ${ }^{36-38}$ 3) $\beta$-blockers inhibit the inflammatory phenotype. Inflammation is a key driver of malignant transformation in hepatocytes, ${ }^{39}$ and 4) $\beta$-blockers have anti-angiogenic effects. ${ }^{40}$

Herrera and colleagues ${ }^{41}$ reported on $173 \mathrm{HCV}$-related cirrhotic patients in a Spanish national registry over a median follow-up period of 11 years. Among them, 73 patients were treated with NSBBs. They reported that the likelihood of HCC diagnosis was significantly higher in patients who were not taking $\beta$-blockers. The multivariate survival analysis using a Cox regression model showed that chronic treatment with $\beta$-blockers was the only independent predictor for the development of HCC (hazard ratio [HR], 0.30; $95 \%$ confidence interval $[\mathrm{CI}], 0.12-0.79 ; P=0.015$ ). These results, although promising, must be interpreted cautiously, since the two groups were not randomized and selection bias cannot be ruled out. For example, one can easily imagine that patients on long-term NSBB treatment are monitored more regularly and closely than those not taking any vasoactive drug therapy. It is possible that closer monitoring of one group may have improved the outcomes.

In 2015, a meta-analysis of 12 trials showed that NSBB reduced HCC incidence by a statistically significant but tiny margin $(-2.6 \%)$. Therefore, the number needed to treat in order to prevent one case of HCC was 38. It remains unclear whether this tiny reduction in incidence was biologically meaningful. Moreover, the meta-analysis was severely underpowered, as there were not 
Ki Tae Yoon, et al. $\beta$-blockers and cirrhosis

enough patients nor HCC cases. Of 1,391 total patients, only 112 developed HCC. The authors estimated that a robustly powered meta-analysis would require approximately 3,700 patients. ${ }^{42}$ Therefore, they emphasized that more clinical trials are required.

\section{NSBBS AND PVT}

$\mathrm{Xu}$ and colleagues ${ }^{43}$ performed a meta-analysis to examine whether $\beta$-blockers increase the risk of PVT. The theoretical underpinning for this hypothesis was that a decrease in portal venous pressure and blood flow may cause turbulent or sluggish flow in this vessel, and thus increase the risk of clotting. These authors analyzed a total of nine studies after eliminating case reports and small series. They concluded that there is a significant 4.6-fold increased risk of PVT in patients taking $\beta$-blockers. However, the quality of these studies was relatively low, with significant heterogeneity in the available dataset.

Therefore, this issue should be resolved through a large controlled prospective observational study. However, even a perfect meta-analysis cannot answer the key question of why such an association exists. Is the association truly cause-and-effect or a correlational artifact? We believe the latter; the association simply reflects the nature of the population being treated with $\beta$-blockers, those with advanced cirrhosis. The risk of PVT is also known to be correlated with the stage of liver failure. Therefore, it may be that $\beta$-blockers do not actually cause PVT, but both are simply associated with advanced liver disease.

\section{NSBBS AND SURVIVAL IN ADVANCED CIRRHO- SIS}

In portal hypertension research, probably the major scientific "shockwave" of 2010 was the aforementioned study by Lebrec's group. ${ }^{9}$ Sersté et al. ${ }^{9}$ reported that NSBBs were associated with a deleterious effect on mortality in patients with refractory ascites. The median survival period was 20 months in patients who were not treated with propranolol, and 5 months in those treated with propranolol ( $95 \% \mathrm{Cl}, 4.8-35.2$ vs. 3.5-6.5 months; $P<0.01)$. Furthermore, the 1-year survival rate was significantly lower in propranolol-treated patients compared to untreated subjects (64\% vs. $19 \%$; $95 \% \mathrm{Cl}, 52-76 \%$ vs. $9-29 \%$; $P<0.01)$. However, this study was retrospective and not randomized, which raises a significant possibility of selection bias. In particular, an issue that may explain the survival difference was the variceal status of the two groups. All of the NSBB-treated patients had esophageal varices, while this percentage in the NSBB-untreated group was only $4 \%$. The third issue was that liver function (total bilirubin) was worse in the $\beta$-blocker-treated group.

After this study was reported, other centers tried to test the hypothesis of possible harm. The literature is now full of conflicting studies (Table 2), and at first glance, drawing even a tentative conclusion about possible harms of $\beta$-blockers seems very difficult. Some studies have shown beneficial effects, ${ }^{26,44,45}$ no difference ${ }^{46,47}$ or deleterious effects. ${ }^{10,48,49}$ However, we believe that a large literature dataset is best examined by systematic review and meta-analyses. Two technically well-performed meta-analyses have been published in the past 5 years, and these will be discussed below.

A 2016 meta-analysis by Chirapongsathorn and colleagues ${ }^{50}$ included studies published up to January 2015, and examined three RCTs and eight observational studies. There were 1,206 deaths in the total cohort of 3,145 patients with ascites. All-cause mortality was similar between the two groups (taking or not taking NSBB) in the overall cohort, as well the subgroups with non-refractory ascites and refractory ascites. Survival rates were similar in the two cohorts, whether examined at 6, 12, 18, or 24 months of follow-up. ${ }^{50}$ The quality of evidence was low in the observational studies, but good in the three RCTs.

In 2019, Wong and coworkers performed another meta-analysis. ${ }^{51}$ This analysis included eight studies, including the three RCTs, and 3,627 total patients with any grade of ascites. They reported that there was no significant increase in the all-cause mortality in patients treated with $\beta$-blockers. ${ }^{51}$ Subgroup analysis of only patients with severe or refractory ascites also showed no significant mortality differences. Only the three RCTs were graded as good quality, while five studies were considered to be fair quality.

Given that two independent and technically well-performed meta-analyses within the past 5 years have both shown a similar lack of harmful effect of $\beta$-blockers on survival in patients with ascites, we believe this issue, at least in cirrhosis with ascites, can now be "laid to rest," and conclude that $\beta$-blockers are not an enemy in this population.

What about the subgroup of patients with compensated cirrhosis? In that regard, Villanueva and colleagues recently reported the results of a randomized, placebo-controlled, multicentric Spanish trial (PREDESCI) in patients with compensated cirrhosis but clinically significant portal hypertension, defined as HVPG $>9$ $\mathrm{mmHg}{ }^{52}$ Patients were randomized to either propranolol or 


\title{
CLINICAL and MOLECULAR
HEPATOLOGY
}

\author{
Volume_27 Number_3 July 2021
}

Table 2. NSBB and survival in patients with cirrhosis

\begin{tabular}{|c|c|c|c|c|c|}
\hline Study & Study population & Drug dose & Study design & Sample size & Authors' conclusion \\
\hline \multicolumn{6}{|l|}{$\begin{array}{l}\text { NSBBs decrease } \\
\text { survival }\end{array}$} \\
\hline $\begin{array}{l}\text { Sersté et al. } \\
\text { (2010) }\end{array}$ & $\begin{array}{l}\text { Cirrhotic patients with } \\
\text { refractory ascites }\end{array}$ & Propranolol 113 \pm 46 mg & Retrospective & 151 & $\begin{array}{l}\text { NSBB deceased 1-year } \\
\text { probability of survival }\end{array}$ \\
\hline $\begin{array}{l}\text { de Souza et al. } \\
\text { (2012) }\end{array}$ & $\begin{array}{l}\text { Cirrhotic patients } \\
\text { with acute variceal } \\
\text { bleeding }\end{array}$ & $\begin{array}{l}\text { Propranolol ( } 40 \mathrm{mg} \text { to } \\
\text { start), nadolol ( } 20 \mathrm{mg} \text { to } \\
\text { start) }\end{array}$ & Retrospective & 89 & $\begin{array}{l}\text { Secondary prophylaxis } \\
\text { decreased survival }\end{array}$ \\
\hline $\begin{array}{l}\text { Kalambokis et al. } \\
\text { (2016) }\end{array}$ & Child-Pugh B and C & $\begin{array}{l}\text { Propranolol (varying } \\
\text { doses) }\end{array}$ & Retrospective & $\begin{array}{c}\text { Child-Pugh B } \\
\text { (n=96), Child-Pugh } \\
\text { C ( } n=75)\end{array}$ & $\begin{array}{l}\text { Decreased survival in } \\
\text { 2-year follow-up in } \\
\text { Child-Pugh B group; } \\
\text { and in 6-month follow- } \\
\text { up in Child-Pugh C } \\
\text { group }\end{array}$ \\
\hline \multicolumn{6}{|l|}{$\begin{array}{l}\text { NSBBs have no } \\
\text { effect on survival }\end{array}$} \\
\hline Sarin et al.. ${ }^{75}$ (2013) & $\begin{array}{l}\text { Consecutive cirrhotic } \\
\text { patients }\end{array}$ & Propranolol 20-360 mg & $\mathrm{RCT}$ & 152 & $\begin{array}{l}\text { No effect on variceal } \\
\text { growth, bleeding, or } \\
\text { mortality }\end{array}$ \\
\hline $\begin{array}{l}\text { Mandorfer et al. } \\
\text { (2014) }\end{array}$ & $\begin{array}{l}\text { Consecutive cirrhotic } \\
\text { patients with } \\
\text { paracentesis; groups } \\
\text { with and without } \\
\text { spontaneous } \\
\text { bacterial peritonitis }\end{array}$ & $\begin{array}{r}\text { Propranolol 20-120 mg, } \\
\text { carvedilol 6.26-25 mg }\end{array}$ & Retrospective & 607 & $\begin{array}{l}\text { Without SBP: increased } \\
\text { LT-free survival; with } \\
\text { SBP: decreased LT-free } \\
\text { survival and higher risk } \\
\text { of HRS }\end{array}$ \\
\hline $\begin{array}{l}\text { de Souza et al. } \\
\text { (2015) }\end{array}$ & $\begin{array}{l}\text { Cirrhosis patients } \\
\text { admitted with } \\
\text { variceal bleeding }\end{array}$ & $\begin{array}{l}\text { Propranolol } 74 \mathrm{mg} \\
( \pm 67 \mathrm{mg}) \text {, carvedilol } \\
6.25 \mathrm{mg} \text {, nadolol } 80 \mathrm{mg}\end{array}$ & Retrospective & 142 & No effect on survival \\
\hline $\begin{array}{l}\text { Bhutta et al. }^{76} \\
\text { (2018) }\end{array}$ & $\begin{array}{l}\text { Hospitalized patients } \\
\text { with cirrhosis and } \\
\text { ascites }\end{array}$ & $\begin{array}{l}\text { Nadolol } 20 \text { mg, } \\
\text { propranolol } 40 \text { mg, } \\
\text { carvedilol } 12.5 \mathrm{mg}\end{array}$ & $\begin{array}{l}\text { Multi-center } \\
\text { database; } \\
\text { retrospective }\end{array}$ & $\begin{array}{l}718 \text { (307/411) (with/ } \\
\text { without } \beta \text {-blockers) }\end{array}$ & $\begin{array}{l}\text { No effect on survival } \\
\text { overall nor refractory } \\
\text { ascites subgroup }\end{array}$ \\
\hline \multicolumn{6}{|l|}{$\begin{array}{l}\text { NSBBs increase } \\
\text { survival }\end{array}$} \\
\hline $\begin{array}{l}\text { Tripathi et al. }{ }^{67} \\
\text { (2009) }\end{array}$ & $\begin{array}{l}\text { Grade II or larger } \\
\text { esophageal varices }\end{array}$ & Carvedilol 12.5 mg/day & $\mathrm{RCT}$ & 152 & $\begin{array}{l}\text { Prevented the first } \\
\text { variceal bleeding }\end{array}$ \\
\hline $\begin{array}{l}\text { Leithead et al. }{ }^{61} \\
\text { (2015) }\end{array}$ & $\begin{array}{l}\text { Ascites and refractory } \\
\text { ascites on transplant } \\
\text { waitlist }\end{array}$ & $\begin{array}{l}\text { Propranolol } 80 \text { mg } \\
\text { (10-240), carvedilol } 6.25 \\
\text { mg (3.125-12.5) }\end{array}$ & Retrospective & 322 & $\begin{array}{l}\text { NSBB reduced waitlist } \\
\text { death }\end{array}$ \\
\hline $\begin{array}{l}\text { Mookerjee et al. }{ }^{26} \\
\text { (2016) }\end{array}$ & $\begin{array}{l}\text { Acute-on-chronic liver } \\
\text { failure }\end{array}$ & $\begin{array}{l}\text { Propranolol } 40 \mathrm{mg} \\
\text { (20-80), nadolol } \\
40 \mathrm{mg}(20-80), \\
\text { carvedilol } 12.5 \mathrm{mg} \\
(6.25-25)\end{array}$ & $\begin{array}{l}\text { Prospective, } \\
\text { observational }\end{array}$ & 349 & $\begin{array}{l}\text { Increased survival } \\
\text { probability }\end{array}$ \\
\hline $\begin{array}{l}\text { Scheiner et al. }{ }^{55} \\
(2017)\end{array}$ & Compensated 68.7\% & 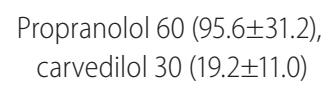 & Retrospective & 176 & $\begin{array}{l}\text { Improved TIPS-/ } \\
\text { transplant-free survival }\end{array}$ \\
\hline Onali et al. ${ }^{77}$ (2017) & $\begin{array}{l}\text { Assessed for LT } \\
\text { suitability }\end{array}$ & $\begin{array}{l}\text { Propranolol } 118 \text { median } \\
80 \text { mg, carvedilol } \\
10 \text { median } 6.25 \text { mg }\end{array}$ & Retrospective & 316 & $\begin{array}{l}\text { Improved overall survival; } \\
\text { no effect on survival in } \\
\text { patients with refractory } \\
\text { ascites }\end{array}$ \\
\hline
\end{tabular}


Table 2. Continued

\begin{tabular}{|c|c|c|c|c|c|}
\hline Study & Study population & Drug dose & Study design & Sample size & Authors' conclusion \\
\hline $\begin{array}{l}\text { Sinha et al. } \\
\text { (2017) }\end{array}$ & $\begin{array}{l}\text { Consecutive cirrhotic } \\
\text { patients }\end{array}$ & Carvedilol $12.5 \mathrm{mg}$ & Retrospective & 325 & $\begin{array}{l}\text { Increased overall } \\
\text { survival and survival } \\
\text { in patients with mild } \\
\text { ascites; no effect } \\
\text { on decompensated } \\
\text { patients }\end{array}$ \\
\hline $\begin{array}{l}\text { Sharma et al. } \\
\text { (2019) }\end{array}$ & $\begin{array}{l}\text { Large varices, no prior } \\
\text { history of bleeding }\end{array}$ & $\begin{array}{l}\text { NSBB, isosorbide- } \\
\text { mononitrate, carvedilol }\end{array}$ & $\begin{array}{l}\text { Systematic review } \\
\text { with network } \\
\text { meta-analysis }\end{array}$ & 3,362 & $\begin{array}{l}\text { Decreased mortality and } \\
\text { first variceal bleeding } \\
\text { with a lower risk of } \\
\text { serious complications }\end{array}$ \\
\hline $\begin{array}{l}\text { Villanueva et al. }{ }^{52} \\
\text { (2019) }\end{array}$ & $\begin{array}{l}\text { Compensated, } \\
\text { significant portal } \\
\text { hypertension without } \\
\text { high-risk varices }\end{array}$ & $\begin{array}{l}\text { Propranolol } \\
\text { (<160 mg), carvedilol } \\
\text { ( } \leq 25 \mathrm{mg} / \text { day) for non- } \\
\text { responders }\end{array}$ & $\mathrm{RCT}$ & 201 & $\begin{array}{l}\text { Increased } \\
\text { decompensation-free } \\
\text { survival; reduced the } \\
\text { incidence of ascites }\end{array}$ \\
\hline $\begin{array}{l}\text { Premkumar et al. } \\
\text { (2020) }\end{array}$ & $\begin{array}{l}\text { Single-center cirrhosis } \\
\text { clinic }\end{array}$ & $\begin{array}{l}\text { Carvedilol (6.25-25 } \\
\text { mg/day) } \pm \text { ivabradine } \\
\text { (5-15 mg/day) }\end{array}$ & $\mathrm{RCT}$ & 189 & $\begin{array}{l}\text { Improved LV diastolic } \\
\text { dysfunction; reduced } \\
\text { decompensation risk; } \\
\text { improved survival }\end{array}$ \\
\hline $\begin{array}{l}\text { Ngwa et al. } \\
\text { (2020) }\end{array}$ & $\begin{array}{l}\text { Candidates for liver } \\
\text { transplantation }\end{array}$ & Propranolol (20 mg/day) & Retrospective & 170 & $\begin{array}{l}\text { Improved short-term } \\
\text { survival }\end{array}$ \\
\hline
\end{tabular}

NSBB, nonselective beta-adrenergic blocker; RCT, randomized controlled trial; SBP, spontaneous bacterial peritonitis; LT, liver transplantation; HRS, hepatorenal syndrome; TIPS, transjugular intrahepatic portosystemic shunt; LV, left ventricle.

carvedilol groups, depending on if they demonstrated an adequate portal-hypotensive response to an intravenous test dose of propranolol or not, respectively. Patients were maintained on chronic drug or placebo therapy over a median follow-up period of 36 months, and the main endpoints were decompensation events, defined as the onset of variceal bleeding, ascites, or encephalopathy. Survival was also tracked.

This study found that long-term treatment with NSBBs improved decompensation-free survival, mainly by decreasing ascites onset. $^{52}$ During the follow-up period, heart rate, cardiac index, and HVPG were significantly decreased in the $\beta$-blocker group compared to the placebo group. Compensated cirrhotic patients with clinically significant portal hypertension, even those who had no or small varices, gradually progressed to develop decompensation. The early use of $\beta$-blockers for these patients reduced the number of decompensation events. ${ }^{52}$ This carefully-conducted RCT argues in favor of long-term NSBB therapy to prevent disease progression and improve survival in patients with compensated cirrhosis and portal hypertension; however, it still needs to be confirmed by other studies.

\section{NSBBS AND KIDNEY FUNCTION}

In 2015, Sersté et al. ${ }^{10}$ reviewed 139 patients with severe alcoholic hepatitis and found that 86 patients (62\%) developed AKI. Patients with NSBBs had comparable Model for End-Stage Liver Disease scores, Maddrey scores, and medical history. Out of 48 NSBB users, 43 (90\%) experienced AKI within 168 days, compared to $50 \%$ in non-NSBB users $(P=0.0001)$. They concluded that NSBB is an independent risk factor for AKI in these patients. ${ }^{10}$ Mandorfer and colleagues ${ }^{53}$ found that $\beta$-blockers significantly increased the risk of HRS in cirrhotic patients with spontaneous bacterial peritonitis. In a cohort of patients with advanced cirrhosis and ascites who were referred for transplantation, Kim and coworkers ${ }^{54}$ also reported that NSBBs were associated with AKI.

Scheiner et al. ${ }^{55}$ investigated patients with compensated cirrhosis. During a 3-year follow-up period, they found that renal function was comparable between patients with and without NSBB treatment; the incidence of AKI was similar, even when the patients had ascites and MAP $<90 \mathrm{mmHg}^{55}$

Ngwa and colleagues ${ }^{56}$ recently reported on a cohort of 170 consecutive patients referred to their center for liver transplant evaluation. Among them, 38 patients were taking $\beta$-blockers. 
There was an increased risk of AKI in the group taking $\beta$-blockers compared to those who were not $(22 \%$ vs. $11 \%, P<0.05)$. However, AKI episodes were mild stage 1 , and all patients recovered. Short-term mortality at 90 days was actually superior in the NSBB group ( $6 \%$ vs. $15 \% ; P<0.05)$.

Since all of these studies were nonrandomized and retrospective, the conclusions must be regarded with caution. For now, there is insufficient evidence to conclude that NSBBs increase the risk of AKI or HRS in patients with ascites.

A related question is whether $\beta$-blockers cause PICD in patients with cirrhosis and refractory ascites. ${ }^{48}$ PICD is usually defined as $>50 \%$ increase in plasma renin activity after large volume paracentesis. In 2011, a hemodynamic study from the Lebrec group showed that PICD developed in eight out of 10 patients with refractory ascites after large volume paracentesis. ${ }^{48}$ The same patients acted as their own controls, and had repeated haemodynamic and blood testing after being weaned off of $\beta$-blockers after their varices had been adequately treated. When these patients were no longer on $\beta$-blockers, only one out of 10 patients developed PICD.

Ferrarese and coworkers ${ }^{57}$ reported discordant results compared to the above study. These authors studied 10 patients with refractory ascites before and after starting NSBB therapy. They found that before $\beta$-blockers, large-volume paracentesis significantly decreased the systemic vascular resistance $(1,896$ to 1,348 dyn $\cdot \mathrm{s} \cdot \mathrm{cm}^{-5} ; P=0.028$ ) and peripheral vascular resistance (measured in the forearm) (47 to $30 \mathrm{mmHg} \cdot \mathrm{min} \cdot \mathrm{dL} \cdot \mathrm{mL}^{-1} ; P=0.04$ ); and cardiac output also increased, but did not reach statistical significance (3.9 to $4.5 \mathrm{~L} / \mathrm{min} ; P=0.06$ ). When patients were taking NSBB, large-volume paracentesis did not significantly decrease systemic vascular resistance $\left(2,002\right.$ vs. 1,798 dyn.s.cm $\left.{ }^{-5} ; P=0.1\right)$ or increase cardiac output (3.4 to $3.8 \mathrm{~L} / \mathrm{min} ; P=0.13$ ). Only two patients developed PICD before taking $\beta$-blockers; this rose to three after the drug was started ( $P=$ nonsignificant). The authors suggested that the negative inotropic effect of NSBB may be compensated by a milder decrease of vascular resistance after paracentesis. Therefore, this study concluded that $\beta$-blockers do not increase the incidence of PICD.

We believe that the scant size of the available literature on PICD with $\beta$-blockers precludes any definitive conclusion at present. Moreover, PICD is a laboratory definition that may have relatively little direct clinical relevance. Therefore, we think it is more important to track clinical and measurable hemodynamic outcomes, such as MAP, cardiac output, hyponatremia, glomerular filtration rate, and occurrence of AKI/HRS.

\section{WINDOW THEORY}

The window theory is based on the concept that the sympathetic nervous system activity is nearly normal in the early stages of cirrhosis, so NSBBs will exert only modest effects at this stage. However, at the later end-stage, although the sympathetic system is highly active, NSBBs, by reducing cardiac contractility and arterial pressure, ${ }^{58}$ may cause tissue hypoperfusion and death, especially when patients have refractory ascites. ${ }^{48} \beta$-blockers are the only vasoactive drugs shown to improve survival in cirrhosis, and this beneficial effect may be limited to the window phase, which is the middle phase between mild and decompensated cirrhosis. However, the exact timing for when this middle phase window should be opened and closed remains unclear.

Krag et al. ${ }^{58}$ proposed that the indications for NSBB usage should be: 1) HVPG $\geq 10 \mathrm{mmHg}$, 2) development of medium-tolarge esophageal varices, and 3) ascites. D'Amico et al. ${ }^{59}$ divided patients with cirrhosis into four stages: stage 1, no varices or ascites; stage 2, varices, no ascites; stage 3: ascites \pm varices; and stage 4: bleeding \pm ascites. Stages 1 and 2 are considered compensated, whereas stages 3 and 4 are decompensated. Whether we can combine the window theory with the cirrhotic stage concept should be further investigated.

Whether the therapeutic window even exists remains debatable. ${ }^{60}$ Leithead et al. ${ }^{61}$ evaluated 322 patients with end-stage liver disease and ascites awaiting liver transplantation, of whom about half were on NSBB treatment. The MELD score, frequency of HCC, and refractory ascites were comparable between the two groups (taking or not taking NSBB). These authors demonstrated that patients on $\beta$-blockers had lower mortality compared to nonNSBB patients. The beneficial effects on survival were even demonstrated in the subgroup of patients with refractory ascites. ${ }^{61}$

\section{$\beta$-BLOCKERS IN CIRRHOSIS: FRIEND OR EN- EMY?}

We believe that although the initial studies seemed to show deleterious effects of beta blockers in patients with refractory ascites, they had some crucial methodological limitations including the retrospective and nonrandomized study designs. On the other hand, more recent studies including carefully conducted prospective randomized trials and several meta-analysis have shown no deleterious effect of beta blockers on survival or even improved survival. Furthermore, the concept of a therapeutic window, while 
interesting and theoretically attractive, is frustratingly difficult to actually test in any kind of clinical study design.

The subgroup question of whether $\beta$-blockers impair renal function in patients with moderate or advanced cirrhosis remains unresolved. There are no existing RCTs in this topic, and the few available studies suffer from significant methodological limitations. The prudent approach espoused by almost all clinicians is to stop $\beta$-blockers in the relatively small percentage of patients who experience a significant drop in arterial pressure. It is likely that this is the group at risk of developing renal dysfunction on NSBB therapy.

Our overall conclusion is that $\beta$-blockers are probably not deleterious; in fact, they may even exert beneficial effects on survival and reducing decompensation. Accordingly, the benefits probably significantly outweigh potential harms.

\section{CARVEDILOL}

Carvedilol is discussed separately as it is a $\beta$-blocker with additional intrinsic $a_{-1}-$ blocking effects, which may be superior to traditional NSBBs in reducing portal pressure ${ }^{62}$ and risk of variceal bleeding ${ }^{63,64}$ However, due to the additional a-blockade, it is much more prone to cause hypotension, so its doses need to start low and be carefully titrated upwards. Current guidelines recommend the use of NSBBs, carvedilol, or variceal band ligation (VBL) for primary prevention of variceal bleeding. ${ }^{6,65,66}$ Carvedilol is effective for primary prevention of variceal bleeding, and some patients who do not respond to traditional NSBBs may respond to carvedilol. ${ }^{67}$

In a recent Cochrane meta-analysis to compare carvedilol with traditional NSBBs, which included 10 RCTs with 810 participants with esophageal varices, there were no clear beneficial or harmful effects of carvedilol versus traditional NSBBs on mortality, upper gastrointestinal bleeding, and adverse events ${ }^{68} \mathrm{~A}$ systematic review with network meta-analysis by Sharma et al. ${ }^{69}$ compared the efficacy of NSBBs, carvedilol, and VBL in the primary prevention of variceal bleeding and overall survival. Even though each treatment decreased all-cause mortality and variceal bleeding risk, none was clearly superior to the others due to a lack of adequately powered studies. The ongoing CALIBRE trial will compare carvedilol vs. VBL as primary prophylaxis in patients with mediumto-large esophageal varices, ${ }^{70}$ with preliminary results perhaps available in late 2021.

Sinha and coworkers ${ }^{45}$ evaluated the effects of long-term carvedilol therapy on mortality in 325 patients with ascites. The long-term overall survival was significantly better in the carvedilol group $(n=132)$ than in the no-carvedilol group (adjusted HR 0.59; $95 \% \mathrm{Cl}, 0.44-0.80)$. However, the survival benefit was no longer significant in the patients with moderate or severe ascites. Unfortunately, like many other studies, this was a nonrandomized retrospective analysis, so possible selection bias significantly limits the robustness of any conclusions.

Recently, Premkumar and coworkers ${ }^{71}$ prospectively evaluated the effects of carvedilol on cardiac function and survival in patients with cirrhosis. Carvedilol alone or carvedilol combined with a novel drug ivabradine were administered to achieve the target heart rate, defined as heart rate reduction to 55-64 beats/min. Ivabradine selectively inhibits the cardiac pacemaker ion current $\left(I_{f}\right)$, and thus reduces the heart rate without affecting blood pressure. $^{72}$ This study found that left ventricular diastolic dysfunction was reversed in the carvedilol+ivabradine group. Various neurohormones, such as norepinephrine, $\mathrm{N}$-terminal brain natriuretic peptide, plasma renin activity, and aldosterone levels were reduced in patients who achieved the target rate reduction. The achievement of the target rate reduction reduced the risk of encephalopathy and AKI, and improved the overall survival. ${ }^{71}$ Therefore, combination therapies, especially with new drugs, show great promise and need further investigation.

\section{CONCLUSION}

In conclusion, the "friendly" qualities of NSBBs in the treatment of cirrhosis include preventing the primary and recurrent variceal hemorrhage, mitigating systemic inflammation, and possibly decreasing the progression of compensated cirrhosis to decompensated. $\beta$-blockers may also slightly decrease the incidence of HCC, although more studies are needed to confirm this. The unfriendly aspects include the widely known adverse drug effects such as asthma, heart block, decreased exercise tolerance, as well as potentially more serious effects such as hypotension and worsening of renal function. There is also a possible association between $\beta$-blockers and the risk of PVT.

Considering the indisputable proof of efficacy in variceal bleeding and the probability or possibility of other significant benefits, we conclude that $\beta$-blockers are much more of a friend than enemy. Indeed, to quote the most famous line from "The Godfather," $\beta$-blockers in patients with cirrhosis should be considered "an offer you can't refuse." 


\section{Authors' contribution}

Ki Tae Yoon and Hongqun Liu searched the literature and wrote a draft, Samuel S. Lee revised the manuscript. All the authors read and approved the final version.

\section{Conflicts of Interest}

The authors have no conflicts to disclose.

\section{REFERENCES}

1. Lebrec D, Nouel O, Corbic M, Benhamou JP. Propranolol--a medical treatment for portal hypertension? Lancet 1980;2:180-182.

2. Hillon P, Lebrec D, Muńoz C, Jungers M, Goldfarb G, Benhamou JP. Comparison of the effects of a cardioselective and a nonselective beta-blocker on portal hypertension in patients with cirrhosis. Hepatology 1982;2:528-531.

3. de Franchis R; Baveno VI Faculty. Expanding consensus in portal hypertension: report of the baveno VI consensus workshop: stratifying risk and individualizing care for portal hypertension. J Hepatol 2015;63:743-752.

4. Lebrec D. Drug therapy for portal hypertension. Gut 2001;49:441442.

5. Jakab SS, Garcia-Tsao G. Evaluation and management of esophageal and gastric varices in patients with cirrhosis. Clin Liver Dis 2020;24:335-350.

6. Korean Association for the Study of the Liver (KASL). KASL clinical practice guidelines for liver cirrhosis: varices, hepatic encephalopathy, and related complications. Clin Mol Hepatol 2020;26:83-127.

7. Brunner F, Berzigotti $A$, Bosch J. Prevention and treatment of variceal haemorrhage in 2017. Liver Int 2017;37(Supp 1):S104-S115.

8. Kim MY, Baik SK, Lee SS. Hemodynamic alterations in cirrhosis and portal hypertension. Korean J Hepatol 2010;16:347-352.

9. Sersté T, Melot C, Francoz C, Durand F, Rautou PE, Valla D, et al. Deleterious effects of beta-blockers on survival in patients with cirrhosis and refractory ascites. Hepatology 2010;52:1017-1022.

10. Sersté $T$, Njimi $H$, Degré $D$, Deltenre $P$, Schreiber J, Lepida $A$, et al. The use of beta-blockers is associated with the occurrence of acute kidney injury in severe alcoholic hepatitis. Liver Int 2015;35:19741982.

11. Qi XS, Bai M, Fan DM. Nonselective $\beta$-blockers may induce development of portal vein thrombosis in cirrhosis. World J Gastroenterol 2014;20:11463-11466.

12. Mookerjee RP, Mehta G. All beta-blockers are created equal, but some beta-blockers are more equal than others. Liver Int 2013; 33:501-503.

13. Poynard T, Calès P, Pasta L, Ideo G, Pascal JP, Pagliaro L, et al. Beta- adrenergic-antagonist drugs in the prevention of gastrointestinal bleeding in patients with cirrhosis and esophageal varices. An analysis of data and prognostic factors in 589 patients from four randomized clinical trials. Franco-italian multicenter study group. N Engl J Med 1991;324:1532-1538.

14. Shin J, Yu JH, Jin YJ, Yim HJ, Jung YK, Yang JM, et al. Acute-onchronic liver failure as a major predictive factor for mortality in patients with variceal bleeding. Clin Mol Hepatol 2020;26:540-553.

15. Kumar M, Kainth S, Choudhury A, Maiwall R, Mitra LG, Saluja V, et al. Treatment with carvedilol improves survival of patients with acute-on-chronic liver failure: a randomized controlled trial. Hepatol Int 2019;13:800-813.

16. Reiberger $T$, Ferlitsch A, Payer BA, Mandorfer M, Heinisch BB, Hayden $\mathrm{H}$, et al. Non-selective betablocker therapy decreases intestinal permeability and serum levels of LBP and IL- 6 in patients with cirrhosis. J Hepatol 2013;58:911-921.

17. Moreau R, Jalan R, Gines P, Pavesi M, Angeli P, Cordoba J, et al. Acute-on-chronic liver failure is a distinct syndrome that develops in patients with acute decompensation of cirrhosis. Gastroenterology 2013;144:1426-1437.e9.

18. Jalan R, Saliba F, Pavesi $M$, Amoros $A$, Moreau $R$, Ginès $P$, et al. Development and validation of a prognostic score to predict mortality in patients with acute-on-chronic liver failure. J Hepatol 2014;61:1038-1047.

19. Cazzaniga M, Dionigi E, Gobbo G, Fioretti A, Monti V, Salerno F. The systemic inflammatory response syndrome in cirrhotic patients: relationship with their in-hospital outcome. J Hepatol 2009;51:475482.

20. Albillos A, Lario M, Álvarez-Mon M. Cirrhosis-associated immune dysfunction: distinctive features and clinical relevance. J Hepatol 2014;61:1385-1396.

21. Seo YS, Shah VH. The role of gut-liver axis in the pathogenesis of liver cirrhosis and portal hypertension. Clin Mol Hepatol 2012;18:337346.

22. Madsen BS, Havelund T, Krag A. Targeting the gut-liver axis in cirrhosis: antibiotics and non-selective $\beta$-blockers. Adv Ther 2013; 30:659-670.

23. Pérez-Paramo M, Muñoz J, Albillos A, Freile I, Portero F, Santos M, et al. Effect of propranolol on the factors promoting bacterial translocation in cirrhotic rats with ascites. Hepatology 2000;31:43-48.

24. Yoon KT, Liu H, Lee SS. Cirrhotic cardiomyopathy. Curr Gastroenterol Rep 2020;22:45.

25. Moctezuma-Velazquez C, Kalainy S, Abraldes JG. Beta-blockers in patients with advanced liver disease: has the dust settled? Liver Transpl 2017;23:1058-1069.

26. Mookerjee RP, Pavesi M, Thomsen KL, Mehta G, Macnaughtan J, Bendtsen F, et al. Treatment with non-selective beta blockers is associated with reduced severity of systemic inflammation and 
improved survival of patients with acute-on-chronic liver failure. J Hepatol 2016;64:574-582.

27. Zambruni A, Di Micoli A, Lubisco A, Domenicali M, Trevisani F, Bernardi M. QT interval correction in patients with cirrhosis. J Cardiovasc Electrophysiol 2007;18:77-82.

28. Tsiompanidis E, Siakavellas SI, Tentolouris A, Eleftheriadou I, Chorepsima S, Manolakis A, et al. Liver cirrhosis-effect on QT interval and cardiac autonomic nervous system activity. World J Gastrointest Pathophysiol 2018;9:28-36.

29. Santeusanio AD, Dunsky KG, Pan S, Schiano TD. The impact of cirrhosis and prescription medications on QTc interval before and after liver transplantation. J Pharm Pract 2019;32:48-53.

30. Bernardi M, Calandra S, Colantoni A, Trevisani F, Raimondo ML, Sica $\mathrm{G}$, et al. Q-T interval prolongation in cirrhosis: prevalence, relationship with severity, and etiology of the disease and possible pathogenetic factors. Hepatology 1998;27:28-34.

31. Kim SM, George B, Alcivar-Franco D, Campbell CL, Charnigo R, Delisle $\mathrm{B}$, et al. QT prolongation is associated with increased mortality in end stage liver disease. World J Cardiol 2017;9:347-354.

32. Peter G, George PC, Villyoth MP, Sivaraman S, Hamza RE, Bahuleyan $S$, et al. QT interval prolongation: a risk factor for development of hepatorenal syndrome in cirrhotic patients with acute variceal bleeding. Trop Gastroenterol 2014;35:157-163.

33. Henriksen JH, Bendtsen F, Hansen EF, Møller S. Acute non-selective beta-adrenergic blockade reduces prolonged frequency-adjusted Q-T interval (QTC) in patients with cirrhosis. J Hepatol 2004;40:239246.

34. Zambruni A, Trevisani F, Di Micoli A, Savelli F, Berzigotti A, Bracci E, et al. Effect of chronic beta-blockade on QT interval in patients with liver cirrhosis. J Hepatol 2008;48:415-421.

35. Ripoll C, Groszmann RJ, Garcia-Tsao G, Bosch J, Grace N, Burroughs $A$, et al. Hepatic venous pressure gradient predicts development of hepatocellular carcinoma independently of severity of cirrhosis. J Hepatol 2009;50:923-928.

36. Al-Wadei HA, Al-Wadei MH, Schuller HM. Prevention of pancreatic cancer by the beta-blocker propranolol. Anticancer Drugs 2009;20:477-482.

37. Liao X, Che X, Zhao W, Zhang D, Bi T, Wang G. The $\beta$-adrenoceptor antagonist, propranolol, induces human gastric cancer cell apoptosis and cell cycle arrest via inhibiting nuclear factor $\mathrm{kB}$ signaling. Oncol Rep 2010;24:1669-1676.

38. Powe DG, Voss MJ, Zänker KS, Habashy HO, Green AR, Ellis IO, et al. Beta-blocker drug therapy reduces secondary cancer formation in breast cancer and improves cancer specific survival. Oncotarget 2010;1:628-638.

39. Thiele M, Wiest R, Gluud LL, Albillos A, Krag A. Can non-selective beta-blockers prevent hepatocellular carcinoma in patients with cirrhosis? Med Hypotheses 2013;81:871-874.
40. Chim H, Armijo BS, Miller E, Gliniak C, Serret MA, Gosain AK. Propranolol induces regression of hemangioma cells through HIF-1amediated inhibition of VEGF-A. Ann Surg 2012;256:146-156.

41. Herrera I, Pascual S, Zapater P, Carnicer F, Bellot P, María Palazón J. The use of $\beta$-blockers is associated with a lower risk of developing hepatocellular carcinoma in patients with cirrhosis. Eur J Gastroenterol Hepatol 2016;28:1194-1197.

42. Thiele M, Albillos A, Abazi R, Wiest R, Gluud LL, Krag A. Nonselective beta-blockers may reduce risk of hepatocellular carcinoma: a meta-analysis of randomized trials. Liver Int 2015;35:2009-2016.

43. Xu X, Guo X, De Stefano V, Silva-Junior G, Goyal H, Bai Z, et al. Nonselective beta-blockers and development of portal vein thrombosis in liver cirrhosis: a systematic review and meta-analysis. Hepatol Int 2019;13:468-481.

44. Kirnake V, Arora A, Gupta V, Sharma P, Singla V, Bansal N, et al. Hemodynamic response to carvedilol is maintained for long periods and leads to better clinical outcome in cirrhosis: a prospective study. J Clin Exp Hepatol 2016;6:175-185.

45. Sinha R, Lockman KA, Mallawaarachchi N, Robertson M, Plevris $J N$, Hayes PC. Carvedilol use is associated with improved survival in patients with liver cirrhosis and ascites. J Hepatol 2017;67:40-46.

46. Bossen L, Krag A, Vilstrup H, Watson H, Jepsen P. Nonselective $\beta$-blockers do not affect mortality in cirrhosis patients with ascites: post hoc analysis of three randomized controlled trials with 1198 patients. Hepatology 2016;63:1968-1976.

47. de Souza AR, La Mura V, Berzigotti A, García-Pagán JC, Abraldes $J G$, Bosch J. Prognosis of acute variceal bleeding: is being on betablockers an aggravating factor? A short-term survival analysis. Hepatology 2015;62:1840-1846.

48. Sersté T, Francoz C, Durand F, Rautou PE, Melot C, Valla D, et al. Beta-blockers cause paracentesis-induced circulatory dysfunction in patients with cirrhosis and refractory ascites: a cross-over study. J Hepatol 2011;55:794-799.

49. Maharaj S, Seegobin K, Perez-Downes J, Bajric B, Chang S, Reddy P. Severe carvedilol toxicity without overdose - caution in cirrhosis. Clin Hypertens 2017;23:25.

50. Chirapongsathorn S, Valentin N, Alahdab F, Krittanawong C, Erwin PJ, Murad MH, et al. Nonselective $\beta$-blockers and survival in patients with cirrhosis and ascites: a systematic review and metaanalysis. Clin Gastroenterol Hepatol 2016;14:1096-1104.e9.

51. Wong RJ, Robinson A, Ginzberg D, Gomes C, Liu B, Bhuket T. Assessing the safety of beta-blocker therapy in cirrhosis patients with ascites: a meta-analysis. Liver Int 2019;39:1080-1088.

52. Villanueva C, Albillos A, Genescà J, Garcia-Pagan JC, Calleja JL, Aracil $C$, et al. $\beta$ blockers to prevent decompensation of cirrhosis in patients with clinically significant portal hypertension (PREDESCI): a randomised, double-blind, placebo-controlled, multicentre trial. Lancet 2019;393:1597-1608. 
53. Mandorfer M, Bota S, Schwabl P, Bucsics T, Pfisterer N, Kruzik M, et al. Nonselective $\beta$ blockers increase risk for hepatorenal syndrome and death in patients with cirrhosis and spontaneous bacterial peritonitis. Gastroenterology 2014;146:1680-1690.e1.

54. Kim SG, Larson JJ, Lee JS, Therneau TM, Kim WR. Beneficial and harmful effects of nonselective beta blockade on acute kidney injury in liver transplant candidates. Liver Transpl 2017;23:733-740.

55. Scheiner B, Parada-Rodriguez D, Bucsics T, Schwabl P, Mandorfer $M$, Pfisterer $N$, et al. Non-selective beta-blocker treatment does not impact on kidney function in cirrhotic patients with varices. Scand J Gastroenterol 2017;52:1008-1015.

56. Ngwa T, Orman E, Gomez EV, Vuppalanchi R, Kubal C, Chalasani N, et al. Non-selective beta blocker use is associated with improved short-term survival in patients with cirrhosis referred for liver transplantation. BMC Gastroenterol 2020;20:4.

57. Ferrarese A, Tikhonoff V, Casiglia E, Angeli P, Fasolato S, Faggian $D$, et al. Hemodynamic evaluation of nonselective $\beta$-blockers in patients with cirrhosis and refractory ascites. Gastroenterol Res Pract 2018;2018:4098210.

58. Krag A, Wiest R, Albillos A, Gluud LL. The window hypothesis: haemodynamic and non-haemodynamic effects of $\beta$-blockers improve survival of patients with cirrhosis during a window in the disease. Gut 2012;61:967-969.

59. D'Amico G, Garcia-Tsao G, Pagliaro L. Natural history and prognostic indicators of survival in cirrhosis: a systematic review of 118 studies. J Hepatol 2006;44:217-231.

60. Garcia-Tsao G. Beta blockers in cirrhosis: the window re-opens. J Hepatol 2016;64:532-534.

61. Leithead JA, Rajoriya N, Tehami N, Hodson J, Gunson BK, Tripathi $D$, et al. Non-selective $\beta$-blockers are associated with improved survival in patients with ascites listed for liver transplantation. Gut 2015;64:1111-1119.

62. Kim SG, Kim TY, Sohn JH, Um SH, Seo YS, Baik SK, et al. A randomized, multi-center, open-label study to evaluate the efficacy of carvedilol vs. propranolol to reduce portal pressure in patients with liver cirrhosis. Am J Gastroenterol 2016;111:1582-1590.

63. Tripathi D, Therapondos G, Lui HF, Stanley AJ, Hayes PC. Haemodynamic effects of acute and chronic administration of low-dose carvedilol, a vasodilating beta-blocker, in patients with cirrhosis and portal hypertension. Aliment Pharmacol Ther 2002;16:373-380.

64. Sinagra $E$, Perricone G, D'Amico M, Tinè F, D'Amico G. Systematic review with meta-analysis: the haemodynamic effects of carvedilol compared with propranolol for portal hypertension in cirrhosis. Aliment Pharmacol Ther 2014;39:557-568.

65. European Association for the Study of the Liver. EASL clinical practice guidelines for the management of patients with decompensated cirrhosis. J Hepatol 2018;69:406-460.
66. Garcia-Tsao G, Abraldes JG, Berzigotti A, Bosch J. Portal hypertensive bleeding in cirrhosis: risk stratification, diagnosis, and management: 2016 practice guidance by the american association for the study of liver diseases. Hepatology 2017;65:310-335.

67. Tripathi D, Ferguson JW, Kochar N, Leithead JA, Therapondos G, McAvoy NC, et al. Randomized controlled trial of carvedilol versus variceal band ligation for the prevention of the first variceal bleed. Hepatology 2009;50:825-833.

68. Zacharias AP, Jeyaraj R, Hobolth L, Bendtsen F, Gluud LL, Morgan MY. Carvedilol versus traditional, non-selective beta-blockers for adults with cirrhosis and gastroesophageal varices. Cochrane Database Syst Rev 2018;10:CD011510.

69. Sharma M, Singh S, Desai V, Shah VH, Kamath PS, Murad MH, et al. Comparison of therapies for primary prevention of esophageal variceal bleeding: a systematic review and network meta-analysis. Hepatology 2019;69:1657-1675.

70. Tripathi D, Hayes PC, Richardson P, Rowe I, Ferguson J, Devine P, et al. Study protocol for a randomised controlled trial of carvedilol versus variceal band ligation in primary prevention of variceal bleeding in liver cirrhosis (CALIBRE trial). BMJ Open Gastroenterol 2019;6:e000290.

71. Premkumar M, Rangegowda D, Vyas T, Khumuckham JS, Shasthry SM, Thomas SS, et al. Carvedilol combined with ivabradine improves left ventricular diastolic dysfunction, clinical progression, and survival in cirrhosis. J Clin Gastroenterol 2020;54:561-568.

72. Thorup L, Simonsen U, Grimm D, Hedegaard ER. Ivabradine: current and future treatment of heart failure. Basic Clin Pharmacol Toxicol 2017;121:89-97.

73. de Souza AR, La Mura V, Reverter E, Seijo S, Berzigotti A, Ashkenazi $E$, et al. Patients whose first episode of bleeding occurs while taking a $\beta$-blocker have high long-term risks of rebleeding and death. Clin Gastroenterol Hepatol 2012;10:670-676; quiz e58.

74. Kalambokis GN, Christodoulou D, Baltayiannis G, Christou L. Propranolol use beyond 6 months increases mortality in patients with Child-Pugh C cirrhosis and ascites. Hepatology 2016;64:1806-1808.

75. Sarin SK, Mishra SR, Sharma P, Sharma BC, Kumar A. Early primary prophylaxis with beta-blockers does not prevent the growth of small esophageal varices in cirrhosis: a randomized controlled trial. Hepatol Int 2013;7:248-256.

76. Bhutta AQ, Garcia-Tsao G, Reddy KR, Tandon P, Wong F, O'Leary $J G$, et al. Beta-blockers in hospitalised patients with cirrhosis and ascites: mortality and factors determining discontinuation and reinitiation. Aliment Pharmacol Ther 2018;47:78-85.

77. Onali S, Kalafateli M, Majumdar A, Westbrook R, O'Beirne J, Leandro $G$, et al. Non-selective beta-blockers are not associated with increased mortality in cirrhotic patients with ascites. Liver Int 2017;37:1334-1344. 